\title{
ZNF224 Gene
}

National Cancer Institute

\section{Source}

National Cancer Institute. ZNF224 Gene. NCI Thesaurus. Code C126563.

This gene plays a role in the negative regulation of gene transcription. 